\title{
Discovery of an introduced Banggai Cardinalfish population in Palu Bay, Central Sulawesi, Indonesia
}

Received: 13 March 2007 / Accepted: 15 March 2007

(C) Springer-Verlag 2007

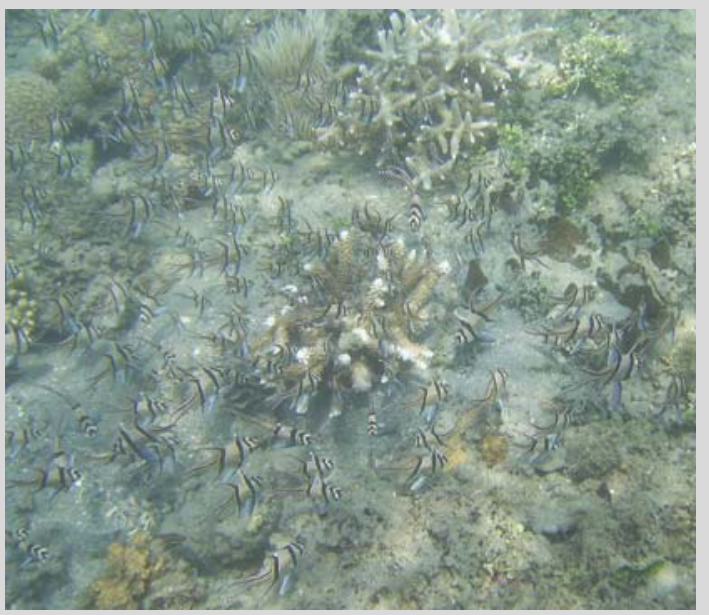

Fig. 1 A typical group of Pterapogon kauderni in Palu Bay

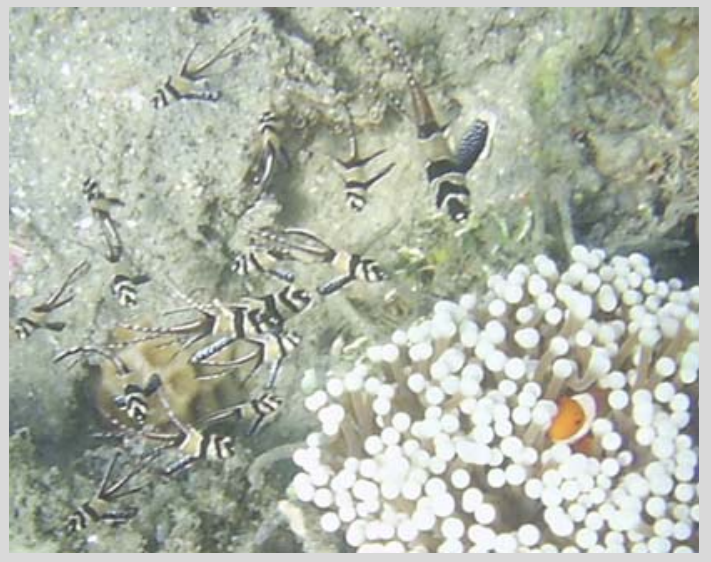

Fig. 2 Juvenile Pterapogon kauderni and anemone fish (Amphiprion sp.) in Palu Bay
The Banggai Cardinalfish Pterapogon kauderni (Koumans, 1933) is a paternal mouthbrooding apogonid with direct development, whose natural distribution is limited to the Banggai Archipelago in Central Sulawesi and a few nearby islands (Vagelli and Erdmann 2002). Much in demand by aquarium hobbyists, the species is traded internationally in large numbers, a fact which has led to a proposal to list the species in CITES Appendix II. Populations outside the endemic area have been reported, seemingly as a result of releases by traders, in Lembeh Straits (Erdmann and Vagelli 2001), Luwuk (Vagelli and Erdmann 2002) and Tumbak (Moore and Ndobe 2005).

In October 2006, a further population was discovered at Mamboro in Palu Bay, on the opposite side of the island of Sulawesi, $440 \mathrm{~km}$ to the west of the Banggai Archipelago.

Observations have since been made on several occasions, including transect data and visual records. Conditions in Palu Bay differ from those in the Banggai Islands, typically, a lower salinity and an almost total lack of Diadema sea urchins with which P. kauderni is generally associated. The substrate is silty sand, with seagrass and outcrops of corals and sponges. Group sizes ranged from 2 to over 200 fish, the majority consists of similar size/age class. Large juvenile and adult fish would swim lazily near the coral outcrops, among seagrass leaves, and in relatively open spaces between suitable refuges (Fig. 1), at depths of $0.5-3 \mathrm{~m}$. All small $(<2 \mathrm{~cm}$ standard length-SL) juveniles observed were found in or near sea anemones, with or without anemone fish (Fig. 2). This population appears to be exploited, as medium sized fish (3-4 cm SL), the size preferred by the trade, were periodically rare, whereas juvenile and larger adults were abundant on all visits.

References

Erdmann MV, Vagelli A (2001) Banggai Cardinalfish invade Lembeh Strait. Coral Reefs 20:252-253

Moore A, Ndobe S (2005) Potensi dan Pentingnya Pengembangan Budidaya In-situ Pterapogon kauderni (Banggai Cardinalfish). InfoMAI, Journal of the Indonesian Aquaculture Society (MAI-Masyarakat Akuakultur Indonesia) 4-2:9-14

Vagelli A, Erdmann MV (2002) First comprehensive survey of the Banggai Cardinalfish, Pterapogon kauderni. Environ Biol Fish 63:1-8

A. Moore $(\bowtie)$

Yayasan Palu Hijau (YPH), Jl Setia Budi Lorong Siswa No 12, Palu 94111, Sulteng (Central Sulawesi), Indonesia e-mail: abigail2105@yahoo.com

S. Ndobe

Sekolah Tinggi Perikanan dan Kelautan (STPL), Palu, Indonesia

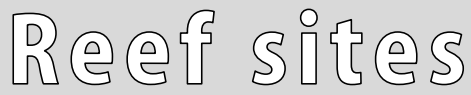

Coral Reefs

DOI $10.1007 / \mathrm{s} 00338-007-0227-9$ 